\title{
MENINGKATKAN PENGETAHUAN GIZI SEIMBANG UNTUK ANAK 1-6 TAHUN MELALUI PENYULUHAN PADA ORANG TUA
}

\author{
Eka Puji Hastuti, Ria Setiasari dan Liana Oktariani \\ STIKES Yatsi Tangerang Banten, Indonesia \\ Email: pujisantosa.id@gmail.com, riasetia233@gmail.com dan \\ oktarianilian@gmail.com
}

\begin{abstract}
The purpose of this study is to know the level of knowledge of parents about balanced nutrition in order to increase parental awareness about the importance of balanced nutrition, especially in children aged 1 to 6 years. This study uses a qualitative approach in which an analysis of how far parents know about the concept of balanced nutrition. The results of this study show that there is still a lack of knowledge and understanding of parents about the importance of balanced nutrition that includes components of calories, proteins, fats, vitamins, minerals and water so that the usual food menu served to their children is still far from balanced nutritional standards. Nutritional insufficiency in children can have a serious impact on the growth and development of children such as decreased endurance, growth disorders and decreased concentration of learning in children who begin to enter school age. Therefore, every parent needs to understand and apply the concept of balanced nutrition in daily life so that the risk of impacts that may arise from nutritional insufficiency in children can decrease.
\end{abstract}

Keywords: balanced nutrition; 1 to 6 years; online counseling

\begin{abstract}
Abstrak
Tujuan penelitian ini adalah mengetahui tingkat pengetahuan orang tua mengenai gizi seimbang dalam rangka meningkatkan kesadaran orang tua mengenai pentingnya gizi seimbang terutama pada anak usia 1 sampai dengan 6 tahun. Penelitian ini mengggunakan pendekatan kualitatif dimana dilakukan analisa seberapa jauh pengetahuan para orang tua mengenai konsep gizi seimbang. Hasil dari penelitian ini menujukkan masih kurangnya tingkat pengetahuan dan pemahaman orang tua mengenai pentingnya gizi seimbang yang mencakup komponen kalori, protein, lemak, vitamin, mineral dan air sehingga menu makanan yang biasa disajikan pada anak-anaknya masih jauh dari standar gizi seimbang. Ketidakcukupan gizi pada anak dapat menimbulkan dampak serius terhadap pertumbuhan dan perkembangan anak seperti penurunan daya tahan tubuh, gangguan pertumbuhan dan menurunnya konsentrasi belajar pada anak yang mulai memasuki usia sekolah. Maka dari itu, tiap orang tua perlu memahami dan menerapkan konsep gizi seimbang dalam keseharian sehingga resiko terjadinya dampak-dampak yang mungkin muncul dari ketidakcukupan gizi pada anak dapat menurun.
\end{abstract}

Kata Kunci: gizi seimbang; 1 s/d 6 tahun; penyuluhan daring 
Coresponden Author

Email: pujisantosa.id@gmail.com Artikel dengan akses terbuka dibawah lisensi

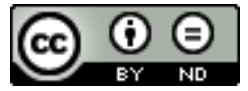

\section{Pendahuluan}

Dampak kemajuan teknologi dapat mempengaruhi pola hidup seseorang dalam hal pemenuhan kebutuhan, salah satunya adalah dalam pemenuhan kebutuhan pangan dalam keluarga. Makanan siap saji saat ini menjadi pilihan masyarakat di mana untuk mendapatkannya tidak memerlukan waktu yang lama dan dapat diperoleh dengan memesan melalui aplikasi secara online jenis makanan tersebut diantaranya adalah pizza, burger, ayam goreng karena makanan tersebut mempunyai rasa yang gurih dan disajikan dalam bentuk yang menarik (Anwar, 2017). Akan tetapi makanan tersebut bukanlah termasuk makanan yang sehat karena didalam makanan tersebut mempunyai kandungan gizinya yang sangat minim tetapi kandungan kalorinya sangat tinggi dan kandungan natrium tinggi (Dunford, Popkin, \& Ng, 2020). Oleh karena itu, makanan siap saji mempunyai dampak terhadap kesehatan misalnya obesitas, tekanan darah tinggi (Pamelia, 2018).

Di Indonesia sejak beberapa tahun yang lalu telah mempunyai masalah dalam status gizi terutama gizi pada anak-anak. Dalam Riskesda 2018 telah menyebutkan bahwa jumlah presentasi status gizi pada usia 0-59 bl kategori gizi buruk sebesar 3,9\%, kategori gizi kurang sebesar 13,8\% dan gizi lebih sebesar sebesar 3,1\% dan pada usia 512 tahun dengan kategori sangat kurus sebanyak 2,4\%, kategori kurus sebesar 6,8\%, kategori gemuk sebesar 10,8\% dan kategori obesitas sebesar 9,2\% (Kementerian Kesehatan, 2014)

Masalah status gizi di Indonesia berdasarkan Riskesda 2018 adalah kelebihan dan kekurangan gizi (Aryastami, 2017). Anak memilih makanan yang disukai dan tidak disukai, adanya makanan siap saji, kurang pengetahuan orang tua terhadap penyajian dan pemenuhan gizi seimbang pada anak yang dipengaruhi oleh faktor sosial ekonomi, budaya, perilaku mempunyai peran terhadap kejadian masalah gizi yang tidak seimbang (Narayan, John, \& Ramadas, 2019). Masalah kekurangan gizi mempengaruhi terhadap pertumbuhan dan perkembangan anak di mana anak mengalami pertumbuhan yang lambat, kemampuan motorik yang kurang, kemampuan kognitif yang kurang di mana dalam jangka panjang akan berpengaruh terhadap produktifitas kerja (Djauhari, 2017). Sebaliknya dengan masalah kelebihan gizi akan mengakibatkan anak menjadi obesitas dan dampak dari obesitas tersebut menyebabkan hipertensi, gula darah yang tinggi (Kementerian Kesehatan., 2014).

Dengan memberikan penyuluhan kepada orang tua tentang gizi seimbang pada anak usia 1-6 tahun diharapkan dapat meningkatkan pengetahuan dan orang tua dapat memenuhi kebutuhan gizi secara seimbang untuk anak-anak. Pengetahuan orang tua mempunyai peranan yang sangat penting dalam gizi seimbang anak-anak (Rifatul 
Masrikhiyah, 2020). Dari uraian diatas, peneliti tertarik untuk mengkaji lebih lanjut tentang pengetahuan orang tua tentang gizi seimbang.

Pemeriksaan antropometri pada anak kelolaan mahasiswa tidak dapat dilakukan secara langsung guna mengetahui status gizi anak. Hasil pengukuran tersebut merupakan data yang pasti untuk memastikan pemahaman orang tua terhadap gizi seimbang, hal itulah yang menjadi alasan mahasiswa melakukan penyuluhan tentang gizi seimbang pada anak.

\section{Metode Penelitian}

Metode yang digunakan dalam penelitian ini adalah metode kualitatif untuk menganalisa tingkat pengetahuan orang tua mengenai konsep gizi seimbang pada anak terutama anak usia 1 sampai dengan 6 tahun. Adapun tahap-tahap yang dilakukan dalam penelitian ini adalah sebagai berikut:

a. Tahap Persiapan

Pembuatan proposal kegiatan merupakan langkah awal dari kegiatan penyuluhan. Disusul dengan pembuatan materi dalam power point disusun secara lengkap, singkat, padat dan jelas yang disertai gambar untuk menarik perhatian peserta sehingga materi yang disampaikan dapat dipahami oleh peserta. Pembuatan link media menggunakan aplikasi google-meet mengingatkan kembali pada peserta untuk mengikuti kegiatan.

b. Tahap Pelaksanaan

Setelah peserta lengkap masuk dalam google-meet moderator membuka acara, ketua kelompok memberikan sambutan pembukaan dilakukan presentasi tentang gizi seimbang, setelah selesai presentasi dilanjutkan sesi tanya jawab pada sesi ini peserta mengutarakan masalah yang dihadapi dan diselesaikan secara bersama.

c. Evaluasi

1. Struktur

Kegiatan dilakukan oleh 20 peserta usia 25 sd 35 dan anak usia 1 s/d 6 tahun sebanyak 10 peserta melalui aplikasi google-meet sesuai dengan rencana yang telah dibuat. Kegiatan dilakukan dengan lancar dan materi yang disampaikan telah dipahami oleh peserta.

2. Proses

Kegiatan dilakukan dari pukul 10.00 s/d 11.30 sesuai dengan jadwal yang telah dibuat.

\section{Hasil dan Pembahasan}

Kegiatan penyuluhan tidak bisa dilakukan secara langsung atau secara tatap muka karena alasan pandemi dan diberlakukannya pembatasan sosial berskala besar di Tangerang dan sekitarnya. Sehingga kegiatan penyuluhan saat ini dilakukan secara virtual dan peserta tetap berada dirumah masing masing. Kegiatan penyuluhan ini dilakukan pada tanggal 13 maret 2021 pukul 10.00 s/d 11.30 yang diikuti oleh 20 
peserta (perempuan usia 25 sd 35 tahun) dan anak anak usia 1-6 tahun sebanyak 10 anak.

Tabel 1

Data Responden Berdasarkan Usia

\begin{tabular}{cccc}
\hline No & Usia (th) & n & $\begin{array}{c}\text { Presentasi } \\
\mathbf{( \% )}\end{array}$ \\
\hline 1 & $25-35$ & 20 & $66 \%$ \\
\hline 2 & $1-6$ & 10 & $34 \%$ \\
\hline & Jumlah & 30 & $100 \%$ \\
\hline
\end{tabular}

Tabel 1 menunjukan presentasi peserta yang hadir berdasarkan usia didapatkan usia $25 \mathrm{sd} 35^{\text {th }}$ sebanyak 20(80\%), dan usia 1-6 tahun sebanyak $10(20 \%)$

Tabel 2

Pengetahuan Sebelum Dilakukan Penyuluhan Gizi Seimbang

\begin{tabular}{cccc}
\hline No & Kriteria & n & $\begin{array}{c}\text { Presentasi } \\
(\boldsymbol{\%})\end{array}$ \\
\hline 1 & Baik & & \\
\hline 2 & Sedang & 15 & $50 \%$ \\
\hline 3 & Kurang & 15 & $50 \%$ \\
\hline & Jumlah & 30 & $100 \%$ \\
\hline
\end{tabular}

Tabel 2 menunjukan data tentang pengetahuan tentang gizi seimbang sebelum dilakukan penyuluhan dengan kriteria sedang sebanyak 15 peserta $(50 \%)$ dan kriteria kurang sebanyak 15 (50\%).

Tabel 3

Pengetahuan Setelah Dilakukan Penyuluhan Gizi Seimbang

\begin{tabular}{llll}
\hline No & Kriteria & $\mathbf{n}$ & $\begin{array}{l}\text { Presentasi } \\
(\boldsymbol{\%})\end{array}$ \\
\hline 1 & Baik & 25 & $83,4 \%$ \\
\hline & & & $16,6 \%$ \\
\hline 3 & Sedang & 5 & $100 \%$ \\
\hline & Kurang & 0 &
\end{tabular}

Tabel 3 menunjukan data tentang pengetahuan tentang gizi seimbang setelah dilakukan penyuluhan dengan kriteria baik sebanyak 25 peserta $(83,4 \%)$ dan kriteria sedang sebanyak $15(16,6 \%)$. 
Setelah dilakukan penyuluhan terdapat peningkatan pengetahuan yang signifikan tentang gizi seimbang untuk anak usia 1-6 tahun pada awalnya sebanyak 50\% menjadi $83,4 \%$.

Kegiatan evaluasi pada akhir kegiatan dilakukan untuk mengetahui tingkat pemahaman orang tua terhadap penyuluhan yang telah diberikan. Evaluasi dilakukan dengan memberikan pertanyaan ke peserta dan peserta bisa menjawab 3 pertanyaan dengan benar.
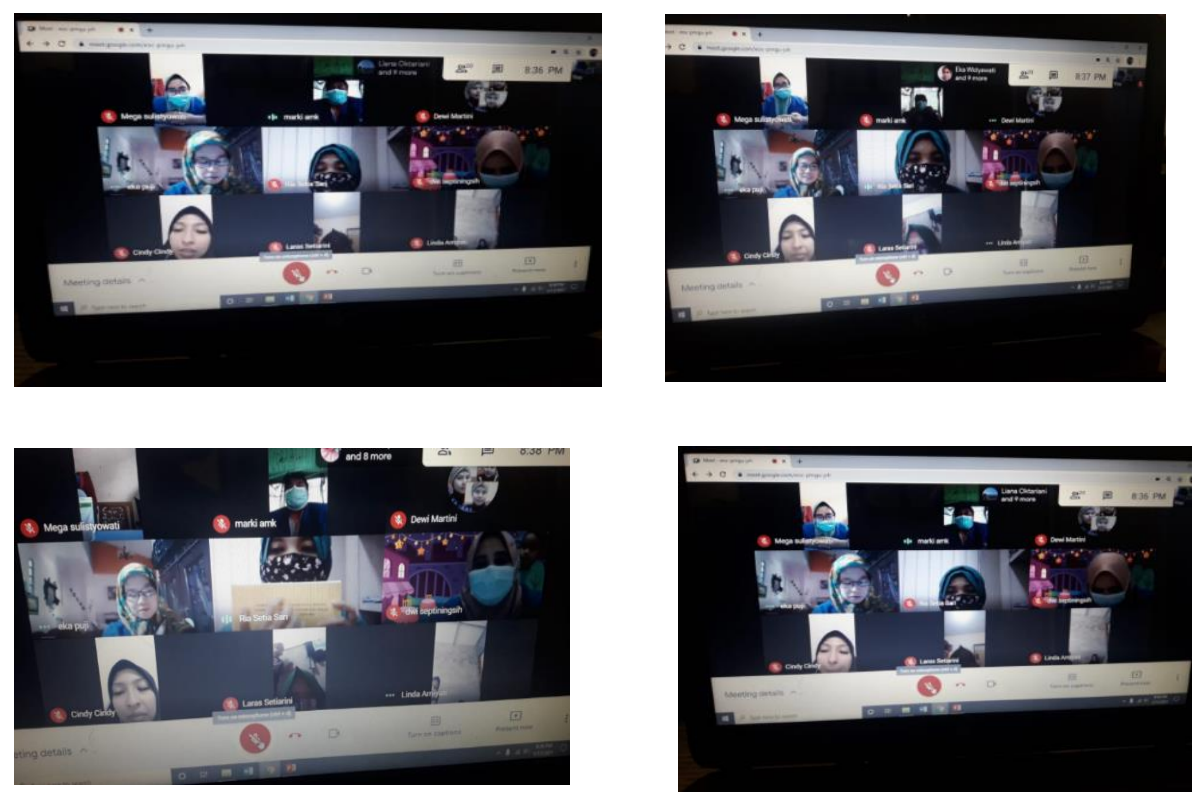

\section{Gambar 1}

(dokumentasi saat tindakan penyuluhan gizi seimbang)

Anak anak berada dalam masa pertumbuhan, hal yang sangat penting pada masa itu adalah pemenuhan nutrisi yang baik dimana akan menentukan kehidupan dimasa yang akan datang, jika dalam masa ini anak kurang baik dalam pemenuhan gizinya akan berdampak terhadap pertumbuhan selanjutnya (Chandra, Suhenny, Kusnady, Utama, \& Han, 2019). Oleh karena itulah orang tua sangat diperlukan dalam hal penyediaan makanan yang bergizi (Rambe, 2017). Dengan mengolah makanan bergizi sendiri orang tua akan melakukan penghematan dibandingkan untuk membeli makanan siap saji atau pesan secara online, orang tua harus bijak dalam pengelolaan ekonomi keluarga (Suryantari \& Patni, 2020). Bahan makanan bergizi sudah banyak tersedia dengan harga yang standar, sehingga diharapkan anak anak setiap harinya mendapatkan gizi yang seimbang.

Kuantitas dan kualitas makanan yang dikonsumsi setiap hari harus mengandung zat tenaga, pembangun dan pengatur, merupakan kunci dari gizi seimbang (Rustiaria, 2017). Status gizi seimbang tersebut sangat ditentukan oleh penyediaan, pengolahan, konsumsi, penyerapan dan penggunaan zat gizi makanan. Status gizi yang baik akan 
meningkatkan kualitas hidup dimasa yang akan datang dan meningkatkan daya tahan tubuh yang sangat diperlukan pada masa pandemi COVID 19 saat ini (Tapung, Regus, Payong, Rahmat, \& Jelahu, 2020). Dengan meningkatnya daya tahan tubuh akan melindungi tubuh dari infeksi dan penyakit menular lainnya (Hidayah, Izah, \& Andari, 2020).

Rentang usia anak 1 s/d 6 tahun ada beberapa anak mengalami susah makan diantaranya anak tidak menyukai makan sayur, anak sudah bisa memilih makanan dan anak lebih menyukai makanan yang siap saji (Gizi et al., 2020). Sebagai orang tua hendaknya mempunyai cara bagaimana anak bisa menyukai makanan yang mengandung gizi seimbang. Orang tua bisa melibatkan anak memilih bahan makanan yang akan dimasak, mengajak langsung dalam mengolah makanan dan penyajian makanan dibuat yang unik sehingga menambah daya tarik anak sendiri saat anak mengikuti kegiatan orang tua bisa menjelaskan kegunaan atau kandungan zat gizi dengan bahasa yang mudah dipahami (Rahayu \& Munastiwi, 2018).

Penyuluhan kesehatan saat ini terdiri dari penyampaian materi gizi seimbang, sesi tanya jawab dimana pada sesi ini membantu peserta dalam menyelesaian masalah yang dihadapi yang berhubungan dengan gizi seimbang pada anak usia 1- 6 tahun. Peserta yang hadir sangat antusias dan aktif serta mengikuti kegiatan dari awal sampai akhir kegiatan, sehingga pengetahuan peserta meningkat yang didapatkan saat dilakukan evaluasi.

\section{Kesimpulan}

Kesimpulan dari uraian kegiatan penyuluhan gizi seimbang tersebut adalah gizi seimbang sangat diperlukan oleh anak usia 1 s/d 6 tahun untuk meningkatkan daya tahan tubuh sehingga anak terhindar dari penyakit infeksi atau penyakit menular lainnya, tumbuh kembang anak, dan dalam jangka waktu yang panjang akan meningkatkan kualitas hidupnya. Oleh karena itu sebagai orang tua harus mempunyai cara lebih banyak untuk menyiasati bagaimana cara memenuhi gizi terhadap anak, pengetahuan orang tua sangat diperlukan dalam hal ini. 


\section{BIBLIOGRAFI}

Anwar, Citra Rosalyn. (2017). Fast Food: Gaya Hidup dan Promosi Makanan Siap Saji. ETNOSIA : Jurnal Etnografi Indonesia, 1(2), 54.

Aryastami, Ni Ketut. (2017). Kajian Kebijakan dan Penanggulangan Masalah Gizi Stunting di Indonesia. Buletin Penelitian Kesehatan, 45(4), 233-240.

Chandra, Wili, Suhenny, Henny, Kusnady, Diding, Utama, Tasik, \& Han, Wong Pong. (2019). Analisis Kedisiplinan Karyawan PT. Total Jaya International. Jurnal Ilmiah Kohesi, 3(1).

Djauhari, Thontowi. (2017). Gizi Dan 1000 Hpk. Saintika Medika, 13(2), 125.

Gizi, Status, Usia, Anak, Sekolah, Pra, Utara, Sumatera, Selatan, Sumatera, \& Riau, Kepulauan. (2020). Anak Usia Prasekolah Terhadap Status Gizi Anak Usia Prasekolah Di Tk Az-Zumar Achmad . Robbi Armansyah Sekolah Tinggi Ilmu Kesehatan Husada Jombang Volume 1 Nomor I : Agustus 2020. 1, 11-16.

Hidayah, Seventina Nurul, Izah, Nilatul, \& Andari, Istiqomah Dwi. (2020). Peningkatan Imunitas dengan Konsumsi Vitamin $\mathrm{C}$ dan Gizi Seimbang Bagi Ibu Hamil Untuk Cegah Corona Di Kota Tegal. Jurnal ABDINUS : Jurnal Pengabdian Nusantara, 4(1 SE-Artikel), 170-174.

Kementerian Kesehatan. (2014). Pedoman Gizi Seimbang. Peraturan Menteri Kesehatan Republik Indonesia Nomor 41 Tentang Pedoman Gizi Seimbang. 1-96.

Narayan, Jitendra, John, Denny, \& Ramadas, Nirupama. (2019). Malnutrition in India: status and government initiatives. Journal of Public Health Policy, 40(1), 126-141.

Pamelia, Icha. (2018). Perilaku konsumsi makanan cepat saji pada remaja dan dampaknya bagi kesehatan. IKESMA, 14(2), 144-153.

Rahayu, Nurliyati, \& Munastiwi, Erni. (2018). Manajemen Makanan Sehat di PAUD. Jurnal Ilmiah Tumbuh Kembang Anak Usia Dini, (2), 65-80. Retrieved from https://www.mendeley.com/catalogue/0b4b0194-02f5-3954-b2b6-bbbbc33914a4/

Rambe, Hartika Lindawati. (2017). Hubungan Pengetahuan Dan Sikap Ibu Tentang Gizi Terhadap Tumbuh Kembang Anak Balitanya Di Taman Kanak-Kanak Imelda Medan. Jurnal Ilmiah Kebidanan Imelda, 3(2), 257-266. Retrieved from http://jurnal.uimedan.ac.id/index.php/Jurnalkebidanan/article/view/137

Rifatul Masrikhiyah. (2020). Peningkatan Pengetahuan Ibu Mengenai Gizi Seimbang Dalam Pemenuhan Gizi Keluarga. Dinamisia: Jurnal Pengabdian Kepada Masyarakat, 4(3), 476-481. 
Eka Puji Hastuti, Ria Setiasari dan Liana Oktariani

Rustiaria, Annora Paramitha. (2017). Pengaruh pengetahuan keuangan, sikap keuangan, dan tingkat pendidikan terhadap perilaku pengelolaan keuangan keluarga. Stie Perbanas Surabaya.

Suryantari, Eka Putri, \& Patni, Ni Luh Putu Suarmi Sri. (2020). Pengaruh pengetahuan keuangan, sikap keuangan, dan tingkat pendidikan terhadap perilaku pengelolaan keuangan keluarga. Journal of Business and Banking, 12(3), 1-16.

Tapung, Marianus Mantovanny, Regus, Max, Payong, Marsel Ruben, Rahmat, Stefanus Turibus, \& Jelahu, Frederikus Maigahoaku. (2020). Bantuan sosial dan pendidikan kesehatan bagi masyarakat pesisir yang terdampak sosial-ekonomi selama patogenesis Covid-19 di Manggarai. Transformasi: Jurnal Pengabdian Masyarakat, 16(1), 12-26. 